\title{
MOTOR SKILLS AS PREDICTORS OF COMPETITORS SELECTION IN KARATE
}

\author{
Izet Kahrović ${ }^{1}$, Srećko Jovanović ${ }^{2}$, Benin Murić ${ }^{1}$, Olivera Radenković ${ }^{1}$, \\ Vladan Milić1, Rifat Mujanović ${ }^{1}$, Sanija Bejtić ${ }^{3}$ \\ ${ }^{1}$ State University of Novi Pazar, Department of Biomedical Sciences, Study Program \\ of Sport and Physical Education, Novi Pazar, Serbia \\ ${ }^{2}$ University of Belgrade, Faculty of Sport and Physical Educatio, Belgrade, Serbia \\ ${ }^{3}$ Elementary School "Halifa bin Zaid Al Naxjan, Novi Pazar, Serbia
}

\begin{abstract}
The goal of the research, which encompassed a wide range of indicators, was to examine the predictive value of motor abilities of karatekas in competitive selections, regarding their competitive orientation towards a certain discipline: kata or kumite. Related to set object and goal of research, a hypothesis was set up: motor skills are significant predictors for competitive selection of karatekas. The sample of respondents was made of male karatekas, aged 12 to 14, who are in regular training process and who compete in current competitive system. The research encompassed 79 karatekas, of which 37 compete in kumite, 23 compete in kata, and 19 in both disciplines. To evaluate general motor skills of karatekas, 15 tests were applied, 3 tests for each of the following set: repetitive strenght, explosive strenght, speed, coordination and flexibility. Descriptive statistical parameters were applied, Multivariate analysis of covariance (MANCOVA) and analysis of covariance (ANCOVA). Statistical significance was analyzed at $(p<0.05)$ level. Results obtained confirmed the set up hypothesis of predictive value of motor abilities of competitive selections karatekas.
\end{abstract}

Key words: KARATE / KATA / KUMITE / MOTOR SKILLS.

\section{INTRODUCTION}

Different moving activities show certain qualitative characteristics of change it. These characteristics of the movable abilities of man are called different terms, but most often they are motor skils (Zivanovic, Stanković, Randjelovic, and Pavlović, 2010). They represent the basis for every learning of moving tasks and can be considered as fundamental values in the total space of the human motor system (Kurelić, Momirović, Stojanović, Šturm, Radojevic, and Viskić-Štalec, 1975).

Defining one of the youngest martial arts disciplines that experienced real expansion in the second half of the last century(Savić, Nićin, Horvat and Kopas, 1994; Cirkovic Jovanović, 2002. Bratic,2006) represents a delicate theoretical and methodological problem. In literature we are faced with numerous attempts to define karate. At the same time, as a rule, polemic, mystique and overall complexity of research karate as a sort of phenomenonis emphasised (Savić et al.,1994; Bratic, 2006; Cirkovic, Jovanović, Kasum, 2010). In this regard, it seems helpful to claim that, instead of the usual question: "when and where it originated", it is more important to answer the question "what is karate" or "what can be defined as karate" (Jovanović, 1992).

Since competitions in karate, according to special rules, take place in two competing disciplines (kata and kumite), the subject of interest in this research is the motor ability that contributes to this differentiation for one of these two disciplines. Therefore, we conducted a study to determine the predictive values of relevant motor skills. 
In relation to the subject and goal set, as well as on the basis of previous researches (show research), we presume that the motor abilities are important predictors of competitive selection in karate.

\section{METHODS}

The sample consisted of male karatekas aged 12 to 14 who were in regular training and competed in the existing system of competition in the Karate Federation of Serbia. This research included a total of $79 \mathrm{ka}-$ ratekas, of which 37 were competitors in the kumite, 23 kata competitors and 19 respondents who competed in both disciplines (Table 1).

Table 1. Caracteristics of the sample

\begin{tabular}{|l|c|c|c|c|}
\hline $\begin{array}{l}\text { THE } \\
\text { YEAR }\end{array}$ & Fighters & $\begin{array}{c}\text { K ata } \\
\text { competitors }\end{array}$ & $\begin{array}{c}\text { K ata }+ \\
\text { fighters }\end{array}$ & Total \\
\hline 2000 & 17 & 6 & 10 & 33 \\
\hline 2001 & 13 & 5 & 4 & 22 \\
\hline 2002 & 7 & 12 & 5 & 24 \\
\hline $\begin{array}{l}\text { IN } \\
\text { TOTAL }\end{array}$ & 37 & 23 & 19 & 79 \\
\hline
\end{tabular}

Significant motorical dimensions were examined using the following measuring instruments: standing long jump (MSLJ), throwing a medicine ball from a lying position (MTFLP), standing triple jump(M-
STJ), 20 meters of sprint from the high start in seconds (M20SS), hand tapping (MHT15), leg tapping (MLT15), forward bend on a bench (MFBB), twist witha stick (MTWS), forward bend from discrepant position (MFBFD), polygon exercise backwards (MPEB), steps to a side in seconds (MSUS), $5 \times 10$ meters (MR5X10M), push-ups (MPU), sit-ups (MSU), chin-ups (MCU).

The results of measurement of motor skills are statistically processed by application of descriptive statistical parameters: aritmetic mean (MEAN), standard deviation (SD), with 95\% reliability interval.

To examine potential differences between groups ('kumite", "kata", "kumite + kata"), Multivariate analysis of covariance (MANCOVA) was applied, while for the group of tests (for excluding the potential influence of body height on differences in motor skills tests) analysis of covariance (ANCOVA) was applied. Statistical significance was analyzed at $(p<0.05)$ level.

\section{RESULTS}

The results of descriptive statistics of the sample variables are shown in Table 2.The fighters had a bit more value than kata competitors,or those who are both kata competitorsand fighters, although these differences are not significant (see the table for details) (Table 3). 
Table 2. Descriptive Statistics [Mean mean (standard deviation), interval reliability]for motor variables (whole sample)

\begin{tabular}{|c|l|l|l|l|l|l|}
\hline \multirow{2}{*}{ VARIABLE } & \multicolumn{2}{|c|}{ Kumite competitors } & \multicolumn{2}{c|}{ Kata competitors } & \multicolumn{2}{c|}{ Kumite + kata competitors } \\
\cline { 2 - 7 } & AS (SD) & $95 \%$ IP & AS (SD) & $95 \%$ IP & AS (SD) & $95 \%$ IP \\
\hline MSLJ & $185.3(22.4)$ & $178.1 \div 192.4$ & $168.0(18.3)$ & $160.5 \div 175.5$ & $178.8(21.4)$ & $169.4 \div 188.2$ \\
\hline MTFLP & $8.3(2.0)$ & $7.7 \div 8.9$ & $6.5(1.5)$ & $5.8 \div 7.1$ & $7.1(1.8)$ & $6.3 \div 7.9$ \\
\hline MSTJ & $540.9(61.7)$ & $521.3 \div 560.5$ & $490.7(47.0)$ & $471.4 \div 509.9$ & $523.5(79.6)$ & $488.6 \div 558.4$ \\
\hline M20SS & $3.8(0.3)$ & $3.7 \div 3.9$ & $4.2(0.4)$ & $4.1 \div 4.4$ & $3.8(0.3)$ & $3.7 \div 4.0$ \\
\hline MHT15 & $30.5(3.8)$ & $29.3 \div 31.7$ & $28.7(3.4)$ & $27.3 \div 30.1$ & $30.2(1.8)$ & $29.4 \div 31.0$ \\
\hline MLT15 & $25.9(2.3)$ & $25.2 \div 26.6$ & $24.1(2.2)$ & $23.2 \div 25.0$ & $24.9(1.7)$ & $24.1 \div 25.6$ \\
\hline MPEB & $12.8(2.2)$ & $12.1 \div 13.5$ & $15.3(3.1)$ & $14.1 \div 16.6$ & $13.5(3.2)$ & $12.1 \div 14.9$ \\
\hline MSUS & $10.1(0.9)$ & $9.8 \div 10.4$ & $11.9(1.5)$ & $11.3 \div 12.5$ & $10.9(0.8)$ & $10.5 \div 11.2$ \\
\hline MR510M & $13.7(0.9)$ & $13.4 \div 14.0$ & $14.8(1.1)$ & $14.4 \div 15.2$ & $14.1(1.0)$ & $13.7 \div 14.6$ \\
\hline MFBB & $43.8(5.9)$ & $41.9 \div 45.6$ & $41.7(7.9)$ & $38.4 \div 44.9$ & $43.5(5.8)$ & $40.9 \div 46.0$ \\
\hline MTWS & $50.8(12.3)$ & $46.9 \div 54.7$ & $46.2(11.8)$ & $41.3 \div 51.0$ & $48.4(13.1)$ & $42.6 \div 54.2$ \\
\hline MFBFD & $47.7(7.4)$ & $45.3 \div 50.0$ & $42.6(9.0)$ & $38.9 \div 46.3$ & $44.3(8.2)$ & $40.7 \div 47.8$ \\
\hline MPU & $26(13)$ & $2 \div 51$ & $18(10)$ & $-1 \div 38$ & $24(11)$ & $3 \div 45$ \\
\hline MSU & $70.2(20.8)$ & $63.6 \div 76.8$ & $47.5(21.8)$ & $38.6 \div 56.4$ & $67.0(24.6)$ & $56.2 \div 77.7$ \\
\hline MCU & $5.6(3.3)$ & $4.5 \div 6.6$ & $3.1(3.2)$ & $1.8 \div 4.4$ & $5.8(4.6)$ & $3.7 \div 7.8$ \\
\hline
\end{tabular}

AS - arithmetic mean; SD - Standard deviation; 95\% CI - Reliabilityinterval

Table 3. Results of multivariate analysis covariance (MANCOVA) motor variables (Factors: age and competitive direction)

\begin{tabular}{|l|c|c|c|}
\hline F values & \multicolumn{3}{|c|}{ FACTORS } \\
\hline Covariance & \multicolumn{3}{|c|}{ Age x orientation } \\
\hline Body height & Age & Orientation & 0.00 \\
\hline $1.71^{* *}$ & 1.05 & $0.00^{*}$ & A \\
\hline
\end{tabular}

${ }^{\star}-p<0.05 ;{ }^{* *}-p<0.01$

Multivariate covariance analysis (Table 3) showed that the influence of body height on the results of motor tests is significant. When the results of a motor test compare relative to the body height, there were no significant differences in the motor between the respondents of different ages, but orientation factor was significant in this case.

Subsequent analysis (Table 4) showed that body height had significant influence on variables MSLJ,
MTFLP, MSTJ, M20SS.Relative to body height, the factor of age was significant in the case MTFLP, MCU, while the "competition orientation" factor was significant in the case of the largest number of variables(MTFLP, M20SS, MHT15, MSUS, MR5X10M, MSU).The differences between age and competition (cross factors) were consistent for all motor variables. 
Table 4. Results of covariance analysis (ANCOVA) for motor variables (factors: age and competition orientation)

\begin{tabular}{|c|c|c|c|c|}
\hline \multirow{2}{*}{ Variables } & Age & Year & Orientation & Year $\mathrm{x}$ orientation \\
\hline & $\mathrm{F}(1 ; 79)$ & $\mathrm{F}(2 ; 79)$ & $\mathrm{F}(2 ; 79)$ & $\mathrm{F}(4 ; 79)$ \\
\hline MSLJ & $6.22 *$ & 2.42 & 2.31 & 2.16 \\
\hline MTFLP & $48.91^{\star *}$ & $3.69^{*}$ & $5.99^{\star *}$ & 0.13 \\
\hline MSTJ & $13.12^{* *}$ & 2.15 & 1.83 & 1.77 \\
\hline M20SS & $5.75^{*}$ & 0.74 & $10.29^{* *}$ & 0.98 \\
\hline MHT15 & 2.18 & 1.95 & 0.48 & 1.38 \\
\hline MLT15 & 1.36 & 0.93 & $3.37^{\star}$ & 2.11 \\
\hline MPEB & 0.01 & 2.95 & $3.61^{\star}$ & 0.59 \\
\hline MSUS & 0.00 & 2.63 & $11.68^{* *}$ & 0.28 \\
\hline MR5X10M & 1.25 & 0.89 & $7.81^{* *}$ & 1.48 \\
\hline MFBB & 2.38 & 1.19 & 0.37 & 0.08 \\
\hline MTWS & 0.11 & 1.49 & 0.59 & 1.20 \\
\hline MFBFD & $8.54^{\star *}$ & 0.11 & 1.36 & 0.55 \\
\hline MPU & 0.87 & $6.25^{* *}$ & 2.00 & 0.49 \\
\hline MSU & 0.29 & 0.81 & $4.89^{*}$ & 0.44 \\
\hline MCU & 0.61 & $3.81 *$ & 1.43 & 2.08 \\
\hline
\end{tabular}

${ }^{*}-p<0.05 ;{ }^{* *}-p<0.01$

The descriptive statistics of motor variables results of the whole sample, [arithmetic mean (standard deviation)] according to age or competition orienta-

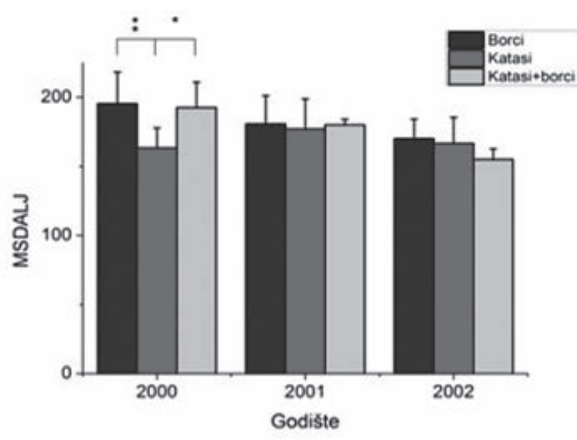

Picture 1. Standing long jump

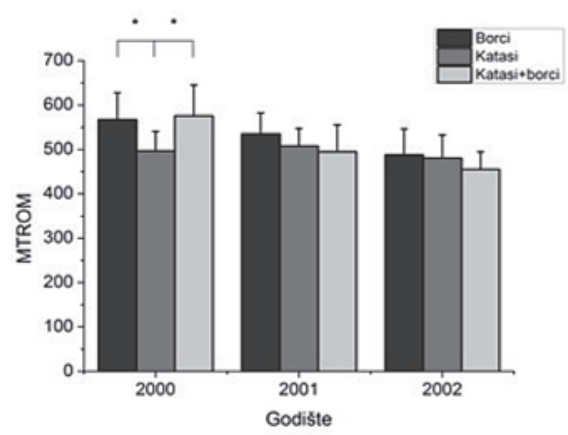

Picture 3. Standing triple jump tion, are shown in the following pictures (Picture 1 to Picture 9).

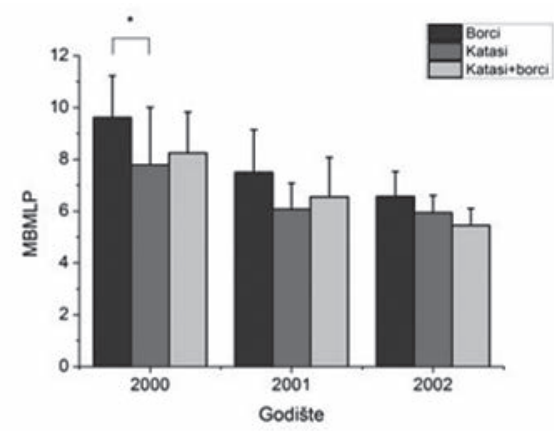

Picture 2. Throwing a medicine ball from a lying position

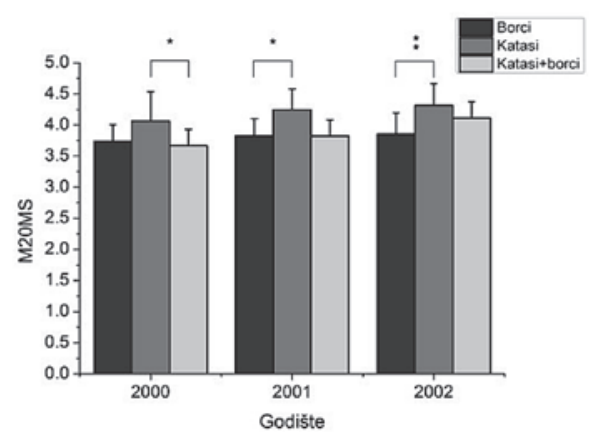

Picture 4. 20 meters of sprint from the high start in seconds 


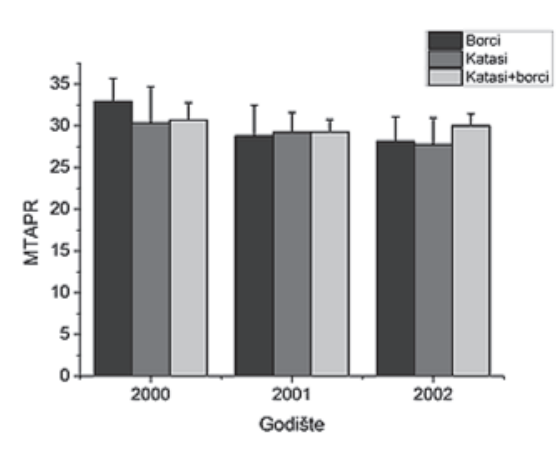

Picture 5. Hand tapping for 15 seconds

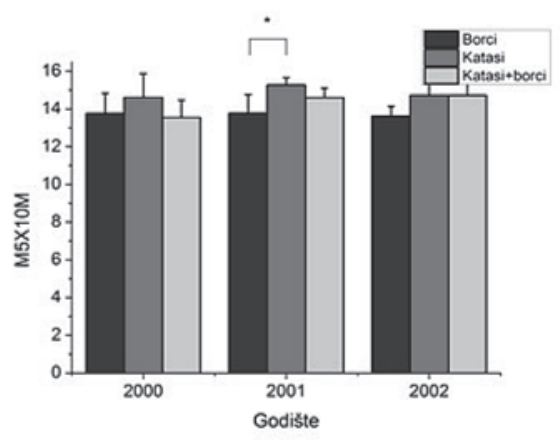

Picture 7. Running 5x10 m

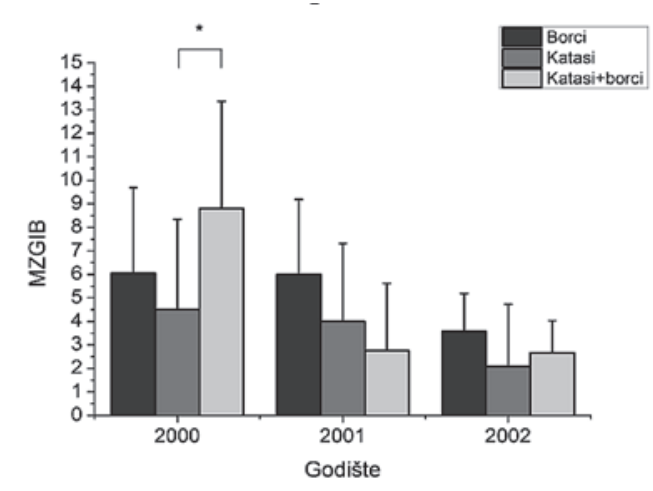

Picture 9. Chin-ups

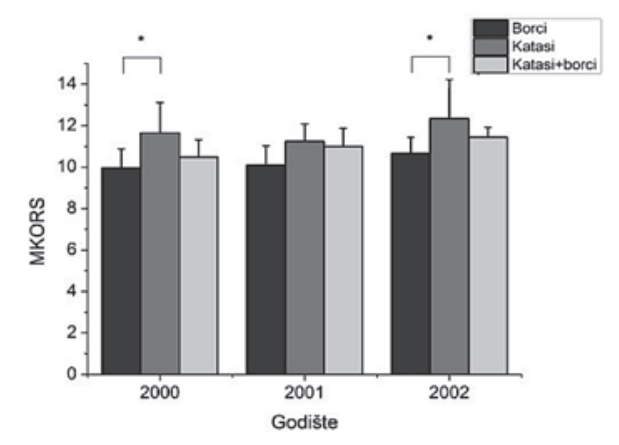

Picture 6. Steps to a side in seconds

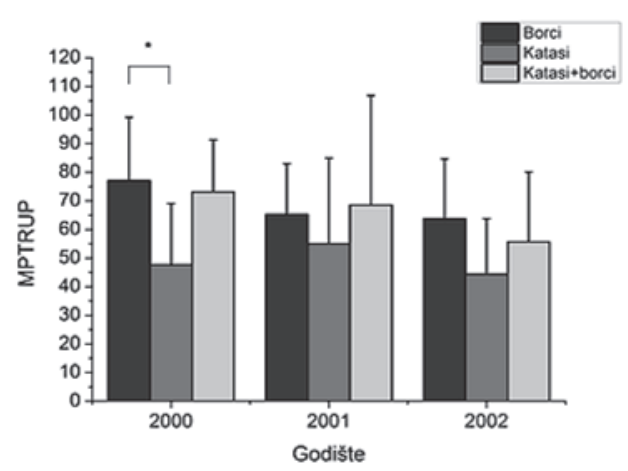

Picture 8. Sit-ups

\section{DISCUSSION}

On the basis of previous research ( Dodera and Doder, 2006; Blazevic, Katic Popović, 2006; Doder and Babiak, 2007; Blazevic, Zaja \& Katic, 2008; Bozanic \& Bešlija, 2010; Gužvica, 2011), we can say that karate skills are positively correlated with basic motor skills. Most significant abilities, those that affect movement and selection techniques that are most often used in combat, are explosive power, speed, coordination and flexibility. As a result of specific motor demands, required in a particular discipline competition, it was expected that some differences between the groups will appear.

Based on the results and descriptive statistics of motor variables in the entire sample,[Mean (standard deviation)] according to the age or discipline, as shown in the pictures (Pictures 1 to 9), we conclude that it is the kumite competitors who have slightly higher values than kata competitors and kata competitors + kumite competitors. In the evaluation variables of explosive strength (MSLJ, MTFLP, MSTJ), the results of kumite competitors 
compared to the results of kata competitors were significantly better only in the oldest respondents (2000), and this difference is reduced when analyzing the results of younger karatekas. The situation is similar at the maximum speed, where in M20SS variable, kumite competitors have significantly better results in relation to the kata competitors, which is particularly manifested in the youngest participants. At speed of frequency movements there are no significant differences between groups except for the oldest competitors (2000), where the results of the kumite competitors are better in comparison to the other two groups of respondents. In coordination, kumite competitors also have better results, though these values are not significantly higher, except in one variable (MSUS), among the oldest (2000) and the youngest (2002) Throw out respondents. Kumite competitors were also significantly better than kata competitors in the variable MR5X10M among the oldest respondents. There was no significant difference in the domain of flexibilitybetween the groups, although the results of the kumite competitors were better, while in the repetitive power, kata competitors' group was significantly weaker than the other two groups of respondents. In only one variable (repetitive force $(\mathrm{MCU})$ ), groups which competes in both fields, is significantly better than in the other two groups, and that at the oldest (2000) competitor.

By comparing the results obtained in our study with recent similar studies (Koropanovski et al., 2011; Koropanovski, 2012), we can say that there are no major differences. As in our study, kumite competitors had better results in speed and explosive power, but the results of flexibility are different. In this domain competitors in kata, in contrast to our study, had better results, slightly below the level of significance. This can be attributed to the fact that in this research respondents are top-level kumite competitors, while kata competitors in modern karate are performing techniques from relatively low poses. For this reason, the training of kata competitors focuses on increasing mobility, especially in lower extremities. In a more recent study, Korapanovski(2012), examined the characteristics of the best competitors in kata and fighting, and applied tests of general and specific motor abilities in different regimesof muscle strain.

Multivariate analysis of covariates indicated that the influence of body height on motor test results is significant. When the results of motor tests compare relative to body height, there are no significant differences in motor skills between respondents of different ages, but the factor of competitive orientation in this case was significant. Subsequent analysis showed that body height had a significant impact on the MSLJ, MTFLP, MSTJ, M20SS, variables. Relative to body height, the age factor was significant in the case of MTFLP, MCU, while the factor "competitive orientation" was significant in the case of most variables (MTFLP, M20SS, MHT15, MSUS, MR5X10M, MSU). Differences by age or competition orientation (crossed factors) were consistent for all motor variables. Subsequent analysis showed that the largest number of significant differences were obtained in the oldest age group (2000) in favor of fighters or fighters + kata competitors, compared to kata competitors.

\section{CONCLUSION}

The aim of the study, which covered a wide range of indicators, was to examine the predictive value of motor skills in karate competition selection, and in their competitive orientation toward specific disciplines of kata or fighting. Therefore, we explored the differences between respondents of different competitive orientations.In this research we tried to determine the eventual impact of motor abilities on the preference of the respondents to the competitive discipline, by testing their differences. To assess general motor skills of karatekas, we applied three tests for most significant motor skills that affect movement and the techniques which are commonly used in sports fight. As a result of specific motor demands in a specific discipline, it was expected that there would be some differences between the groups of examined karatekas, and it was confirmed by the obtained results. This confirmed the established hypothesis on the predictive values of motor skills in the competitive selection of karatekas. This confirmed the established hypothesis on the predictive values of motor skills in competitive selection of karatekas, but it should be noted that the research was carried out on a population of karatekas who are in a period of intensive growth and development, and similar studies should be done with a population of older adults in order to collect even more reliable results. The study is a 
major contribution to karate because of the very small number of studies devoted to study the differences between the different competition orien-

\section{REFERENCES}

1. Bratić, M. (2006). Borenja. [Fighting. In Serbian]. Niš, Faculty of sport and physical education.

2. Blažević, S., Katić, R.\&Popović, D. (2006). The effect of Motor Abilities on Karate Performance. Coll. Antropol., 30 (2), 327-333.

3. Blažević, S., Žaja, M., \&Katić, R. (2008). Integration and basic specific motor abilities in elite karateka. Zagreb: $5^{\text {th }}$ International Scientific Conference on Kinesiology - Kinesiology research blends and applications, 891-893.

4. Božanić, A., \& Bešlija, T. (2010). Relations Between fundamental motor skills and specific karate tech nique in 5-7 year old beginners. Sport Science 3 (1),79-83.

5. Doder, D., \& Doder, R. (2006). The influence of anthropological characteristics on the performance of kicking with the foot forward. Matica Srpska, Collection of papers in natural sciences, 111, 4554.

6. Doder, D., \& Babiak, J. (2007). Connection of explosive power with top results in karate. Montenegrin Sport Academy „Sport Mont“ 12,13,14 (V), 784-791.

7. Gužvica, M. (2011). Predictability of the performance of foot techniques in karate sports based on some motor skills and morphological characteristics. 3. International Scientific Congress "Anthropological Aspects of Sport, Physical Education and Recreation", Banja Luka, Collection of papers,94-104.

8. Jovanović, S. (1992). Karate 1 - Teorijske osnove [Karate 1 - Theoretical groundwork. In Serbian]. Novi Sad.Sports World. tation of karatekas. The results of this research can serve as the basis and impetus for future research in karate.

9. Koropanovski, N., Berjan, B., Bozic, P. B., Pazin, N., Sanader, A., Jovanovic, S., \&Jaric, S. (2011). Anthropometric and Physical Performance Profiles of Elite Karate Kumite and Kata Competitors. Journal of Human Kinetics, 30, 107-114.

10. Korapanovski, N. (2012). Karakteristike neuro-mišićne funkcije vrhunskih karatista različite specijalizacije. [Characteristics of neuro-muscular functions of top class karatekas with different specializations. In Serbian]. Unpublished doctoral dissertation, Belgrade: Faculty of sport and physical education.

11. Kurelić, N., Momirović, K., Stojanović, M., Šturm, J., Radojević, Đ. \& Viskić-Štalec, N. (1975). Struktura i razvoj morfoloških i motoričkih dimenzija omladine. [Structure and development of morphological and motor dimensions of youth In Serbian.] .Belgrade: Faculty of sport and physical education.

12. Savić, M.,Nićin, Đ., Horvat, S. \&Kopas, J. (1994). Borilački sportovi [Combat sports. In Serbian]. Novi Sad: Faculty of physical education.

13. Ćirković, Z., \& Jovanović, S. (2002). Borenja, boks $i$ karate. [Fighting, boxing-karate]. Belgrade: Faculty of sport and physical education.

14. Ćirković, Z., Jovanović, S., \& Kasum, G. (2010). Borenja. [Fighting. In Serbian]. Belgrade, Faculty of sport and physical education.

15. Živanović, N., Stanković, V., Ranđelović, N., \& Pavlović, P. (2010). Teorija fizičke kulture. [Theory of physical culture. In Serbian]. Nis, Faculty of sport and physical education.. 


\title{
CAPACIDADES MOTRICES COMO PREDICTORES DE LA SELECCIÓN COMPETITIVA EN KARATE
}

\begin{abstract}
Resumen
El objetivo del presente estudio es investigar el valor predictivo de las capacidades motrices de los jóvenes karatekas en su orientación competitiva hacia la disciplina concreto: para katas o para luchas. En relación con el objeto y objetivo fijados, se estableció la hipótesis que las capacidades motrices son un predictor importante de la selección competitiva en karate. La muestra de los examinados eran los karatekas varones, de edades cronológicas de 12 a 14 años quienes están en un proceso de entrenamiento regular y compiten en marco del sistema actual de competencias. La investigación abarcó 79 karatekas en total, de los que los 37 competidores en luchas, 23 competidores en katas y los 19 examinados que computen en las dos disciplinas. Para evaluar la motricidad general de los examinados se han aplicado 15 pruebas como sigue: tres pruebas para la fuerza repetitiva, fuerza explosiva, rapidez, coordinación y flexibilidad respectivamente. Se han establecido los parámetros estadísticos descriptivos, se ha hecho el análisis extendida de covarianza (MANCOVA) y análisis de covarianza (ANCOVA). La importancia estadística se ha analizado en el nivel $(\mathrm{p}<0.05)$. Los resultados obtenidos confirman la hipótesis establecida de valores predictivos de las capacidades motrices escogidas en la selección competitiva de karatekas.
\end{abstract}

Palabras claves: KARATE / CAPACIDADES MOTRICES / NIÑOS

Received: 16.11 .2017

Accepted: 07.03. 2018 


\title{
МОТОРИЧКЕ СПОСОБНОСТИ КАО ПРЕДИКТОРИ ТАКМИЧАРСКЕ СЕЛЕКЦИЈЕ У КАРАТЕУ
}

\author{
Изет Кахровић ${ }^{1}$, Срећко Јовановић ${ }^{2}$, Бенин Мурић ${ }^{1}$, Оливера Раденковић ${ }^{1}$, \\ Владан Милић ${ }^{1}$, Рифат Мујановић ${ }^{1}$, Санија Бејтић ${ }^{3}$ \\ ${ }^{1}$ Државни Универзитет у Новом Пазару, Департман за биомедицинске науке, Студијски програм \\ Спорт и физичко васпитање, Србија \\ ${ }^{2}$ Универзитет у Београду, Факултет спорта и физичког васпитања, Србија \\ ${ }^{3}$ Основна школа „Халифа бин Заид Ал-НАхјан, Нови Пазар, Србија
}

\begin{abstract}
Сажетак
Циљ ове студије је да се испита предиктивна вредност моторичких способности младих каратиста у њиховој такмичарској оријентацији према конкретној дисциплини: за кате или борбе.У односу на постављени предмет и циљ, утврђена је хипотеза да су моторичке способности значајан предиктор такмичарске селекције у каратеу. Узорак испитаника чинили су каратисти мушког пола, хронолошке старости од 12 до 14 година који су у редовном тренажном процесу и такмиче се у оквиру актуелног система такмичења. Истраживањем је обухваћено укупно 79 каратиста, од чега 37 такмичара у борбама, 23 такмичара у катама и 19 испитаника који се такмиче у обе дисциплине. Како би проценили општу моторику испитаника, примењено је 15 тестова, и то: по три теста за репетитивну снагу, експлозивну снагу, брзину, координацију и гипкост. Утврђени су дескриптивни статистички параметри, извршене су мултиваријантна анализа (MANCOVA) и анализа коваријансе (ANCOVA). Статистичка значајност анализирана је на нивоу $(\mathrm{p}<0.05)$. Добијени резултати потврђују постављену хипотезу о предиктивним вредностима одабраних моторичких способности у такмичарској селекцији каратиста.
\end{abstract}

Кључне речи: КАРАТЕ / МОТОРИЧКЕ СПОСОБНОСТИ / ДЕЦА /

\section{УВОД}

При различитим кретним активностима, испољавају се поједине квалитативне карактеристике кретних могућности човека. Те карактеристике кретних могућности човека означавају се различитим терминима, али најчешће као моторичке способности (Живановић и сар. 2010). Представљају основу за свако учење кретних задатака, па се може сматрати да представљају базичну вредност у укупном простору човекове моторике (Курелић и сар, 1975).

Дефинисање каратеа као једне од најмлађих борилачких дисциплина, која је доживела праву експанзију у другој половини прошлог века ( Савић и сар. 1994; Ћирковић и Јовановић, 2002; Братић, 2006), представља деликатан теоријско - методолошки проблем. У литератури се сусре- ћемо са бројним покушајима дефинисања. При том се, као по правилу, истиче полемичност, мистичност и свеукупна сложеност истраживања каратеа, као својеврсног феномена (Савић и сар., 1994; Братић, 2006; Ћирковић и Јовановић, Касум, 2010). У том смислу, чини се корисним тврдња да је, уместо уобичајеног питања: „када и где је настао“, значајније одговорити на питање: „шта је карате“, или „шта све јесте карате“ (Јовановић, 1992).

Пошто се такмичења у каратеу одвијају у две такмичарске дисциплине (кате и борбе), предмет интересовања у овом истраживању су моторичке способности које доприносе тој диференцијацији. Зато је, током овог истраживања, извршено тестирање релевантних моторичких способности с циљем утврђивања њихових предиктивних вредности. 
У односу на постављени предмет и циљ, као и на основу досадашњих истраживања, постављена је хипотеза: моторичке способности су значајан предиктор такмичарске селекције у каратеу.

\section{МЕТОД РАДА}

\section{Узорак испитаника}

Узорак испитаника чинили су каратисти мушког пола хронолошке старости од 12 до 14 година који су у редовном тренажном процесу и такмиче се у оквиру актуелног система такмичења у Карате федерацији Србије. Истраживањем је обухваћено укупно 79 каратиста, од чега 37 такмичаpa у борбама, 23 такмичара у катама и 19 испитаника који се такмиче у обе дисциплине (Табела 1).

Табела 1 Карактеристике узорка

\begin{tabular}{|l|c|c|c|c|}
\hline Годиште & Борци & Каташи & Каташи+Борци & Укупно \\
\hline 2000 & 17 & 6 & 10 & 33 \\
\hline 2001 & 13 & 5 & 4 & 22 \\
\hline 2002 & 7 & 12 & 5 & 24 \\
\hline Укупно & 37 & 23 & 19 & 79 \\
\hline
\end{tabular}

\section{Варијабле}

Значајне моторичке димензије процењене су помоћу следећих мерних инструмената: скок удаљ с места (МСДАЉ), бацање медицинке из лежећег положаја (МБМЛП), троскок из места (МТРОМ), 20 метара спринта из високог старта у секундама (M20MC), тапинг руком (МТАПР), тапинг ногом
(МТАПН), дубоки претклон на клупици (МДПРК), искрет палицом (МИСКП), претклон раскорачно (МПРАС), полигон натрашке (МПОЛН), кораци у страну у секундама (МКОУРС), 5х10 метара (М5Х10М), склекови (МСКЛЕК), подизање трупа из лежећег положаја (МРТРУП), згибови на вратилу (МЗГИБ).

\section{Статистичка обрада и анализа}

Резултати мерења моторичких способности статистички су обрађени применом дескриптивних статистичких параметара: аритметичка средина (MEAN), стандардна девијација (SD), и 95\% интервал поузданости. Да би се испитале потенцијалне разлике између група („борци“, „каташи“; „борци+каташи“), примењена је мултиваријантна анализа варијансе (MANOVA), док ће за групу тестова (са циљем да се искључи потенцијални утицај телесне висине на разлике у резултатима моторичких тестова) применити мултиваријантна анализа коваријансе (ANCOVA). За границу значајности одабране су вредности нивоа поверења од $\mathrm{p}<0.05$.

\section{РЕЗУЛТАТИ}

Резултати дескриптивне статистике варијабли узорка приказани су у табели 2. Борци су имали незнатно веће вредности од каташа, односно каташа+бораца, иако те разлике нису биле значајне (за детаље погледати табелу 3 ). 
Кахровић И. и сар., Моторичке способности као предиктори..., ФИЗИЧКА КУЛТУРА 2018; 72 (1): 49-56

Табела 2 Дескриптивни показатељи мерења

(аритметичка средина, интервал поузданости за моторичке варијабле, цео узорак)

\begin{tabular}{|l|c|c|c|c|c|c|}
\hline \multirow{2}{*}{ Варијабла } & \multicolumn{2}{|c|}{ Борци } & \multicolumn{2}{c|}{ Каташи } & \multicolumn{2}{c|}{ Борци + Каташи } \\
\cline { 2 - 7 } & AS (SD) & $95 \%$ IP & AS (SD) & $95 \%$ IP & AS (SD) & $95 \%$ IP \\
\hline МСДАљ & $185.3(22.4)$ & $178.1 \div 192.4$ & $168.0(18.3)$ & $160.5 \div 175.5$ & $178.8(21.4)$ & $169.4 \div 188.2$ \\
\hline МБМЛП & $8.3(2.0)$ & $7.7 \div 8.9$ & $6.5(1.5)$ & $5.8 \div 7.1$ & $7.1(1.8)$ & $6.3 \div 7.9$ \\
\hline МТРОМ & $540.9(61.7)$ & $521.3 \div 560.5$ & $490.7(47.0)$ & $471.4 \div 509.9$ & $523.5(79.6)$ & $488.6 \div 558.4$ \\
\hline М20МС & $3.8(0.3)$ & $3.7 \div 3.9$ & $4.2(0.4)$ & $4.1 \div 4.4$ & $3.8(0.3)$ & $3.7 \div 4.0$ \\
\hline МТАПР & $30.5(3.8)$ & $29.3 \div 31.7$ & $28.7(3.4)$ & $27.3 \div 30.1$ & $30.2(1.8)$ & $29.4 \div 31.0$ \\
\hline МТАПН & $25.9(2.3)$ & $25.2 \div 26.6$ & $24.1(2.2)$ & $23.2 \div 25.0$ & $24.9(1.7)$ & $24.1 \div 25.6$ \\
\hline МПОЛН & $12.8(2.2)$ & $12.1 \div 13.5$ & $15.3(3.1)$ & $14.1 \div 16.6$ & $13.5(3.2)$ & $12.1 \div 14.9$ \\
\hline МКОРС & $10.1(0.9)$ & $9.8 \div 10.4$ & $11.9(1.5)$ & $11.3 \div 12.5$ & $10.9(0.8)$ & $10.5 \div 11.2$ \\
\hline М5Х10М & $13.7(0.9)$ & $13.4 \div 14.0$ & $14.8(1.1)$ & $14.4 \div 15.2$ & $14.1(1.0)$ & $13.7 \div 14.6$ \\
\hline МДПРК & $43.8(5.9)$ & $41.9 \div 45.6$ & $41.7(7.9)$ & $38.4 \div 44.9$ & $43.5(5.8)$ & $40.9 \div 46.0$ \\
\hline МИСКП & $50.8(12.3)$ & $46.9 \div 54.7$ & $46.2(11.8)$ & $41.3 \div 51.0$ & $48.4(13.1)$ & $42.6 \div 54.2$ \\
\hline МПРАС & $47.7(7.4)$ & $45.3 \div 50.0$ & $42.6(9.0)$ & $38.9 \div 46.3$ & $44.3(8.2)$ & $40.7 \div 47.8$ \\
\hline МСКЛЕК & $26(13)$ & $2 \div 51$ & $18(10)$ & $-1 \div 38$ & $24(11)$ & $3 \div 45$ \\
\hline МРТРУП & $70.2(20.8)$ & $63.6 \div 76.8$ & $47.5(21.8)$ & $38.6 \div 56.4$ & $67.0(24.6)$ & $56.2 \div 77.7$ \\
\hline МЗГИБ & $5.6(3.3)$ & $4.5 \div 6.6$ & $3.1(3.2)$ & $1.8 \div 4.4$ & $5.8(4.6)$ & $3.7 \div 7.8$ \\
\hline
\end{tabular}

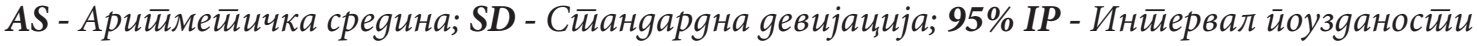

Табела 3 Резултати мултиваријантне анализе коваријансе (MANCOVA-e) за моторичке варијабле (Фактор узраст и такмичаркско усмерење)

\begin{tabular}{|c|c|c|c|}
\hline \multicolumn{2}{|c|}{ F вредности } \\
\hline Коваријанта & \multicolumn{3}{|c|}{ Фактори } \\
\hline Телесна висина & Годиште & Усмерење & Годиште х усмерење \\
\hline $1.71^{\star *}$ & 1.05 & $0.00^{*}$ & 0.00 \\
\hline
\end{tabular}

${ }^{*}-p<0,05 ;{ }^{* *}-p<0,01$

Мултиваријантна анализа коваријансе ( Табела 3) указала је да је утицај телесне висине на резултате моторичких тестова значајан. Када се резултати моторичких тестова пореде релативно у односу на телесну висину, није било значајних разлика у анализирној моторици између испитаника различитог узраста, али је зато фактор спортског усмерења у овом случају био значајан.

Детаљна анализа (Табела 4) показала је да је телесна висина имала значајан утицај на варијабле
МСДАљ, МБМЛП, МТРОМ, М20МС. Релативно у односу на телесну висину, фактор узраст био је значајан у случају МБМЛП, МЗГИБ, док је фактор „такмичарско усмерење“ био значајан у случају највећег броја варијабли (МБМЛП, М20МС, МТАР, МКОРС, М5Х10М, МРТРУП). Разлике у односу на узраст, односно такмичарско усмерење (укрштени фактори) биле су конзистентне за све моторичке варијабле. 
Кахровић И. и сар., Моторичке способности као предиктори..., ФИЗИЧКА КУЛТУРА 2018; 72 (1): 49-56

Табела 4 Резултати анализе коваријансе (ANKOVE) за моторичке варијабле (Фактор узраст и такмичарско усмерење)

\begin{tabular}{|l|c|c|c|c|}
\hline \multirow{2}{*}{ Варијабле } & Узраст & Годиште & Усмерење & Годиште х усмерење \\
\cline { 2 - 5 } & $\mathrm{F}(1 ; 79)$ & $\mathrm{F}(2 ; 79)$ & $\mathrm{F}(2 ; 79)$ & $\mathrm{F}(4 ; 79)$ \\
\hline МСДАљ & $6.22^{\star}$ & 2.42 & 2.31 & 2.16 \\
\hline МБМЛП & $48.91^{\star *}$ & $3.69^{*}$ & $5.99^{\star *}$ & 0.13 \\
\hline МТРОМ & $13.12^{\star *}$ & 2.15 & 1.83 & 1.77 \\
\hline МТАПР & $5.75^{\star}$ & 0.74 & $10.29^{\star *}$ & 0.98 \\
\hline МТАПН & 2.18 & 1.95 & 0.48 & 1.38 \\
\hline МПОЛН & 1.36 & 0.93 & $3.37^{\star}$ & 2.11 \\
\hline МКОРС & 0.01 & 2.95 & $3.61^{\star}$ & 0.59 \\
\hline М5Х10М & 0.00 & 2.63 & $11.68^{\star *}$ & 0.28 \\
\hline МДПРК & 1.25 & 0.89 & $7.81^{\star *}$ & 1.48 \\
\hline МИСКП & 2.38 & 1.19 & 0.37 & 0.08 \\
\hline МПРАС & 0.11 & 1.49 & 0.59 & 1.20 \\
\hline МСКЛЕК & $8.54^{\star *}$ & 0.11 & 1.36 & 0.55 \\
\hline МРТРУП & 0.87 & $6.25^{\star *}$ & 2.00 & 0.49 \\
\hline МЗГИБ & 0.29 & 0.81 & $4.89^{*}$ & 0.44 \\
\hline
\end{tabular}

${ }^{*}-p<0,05 ;{ }^{* *}-p<0,01$;

Резултати дескриптивне статистике моторичких варијабли читавог узорка, [аритметичка средина (стандардна девијација)] према узрасту, од-

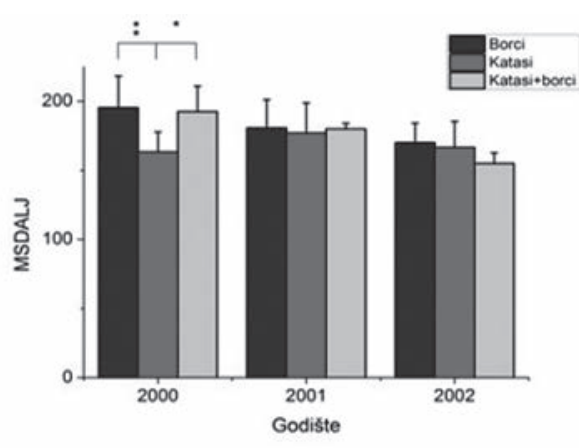

Слика 1 Скок удаљ из места

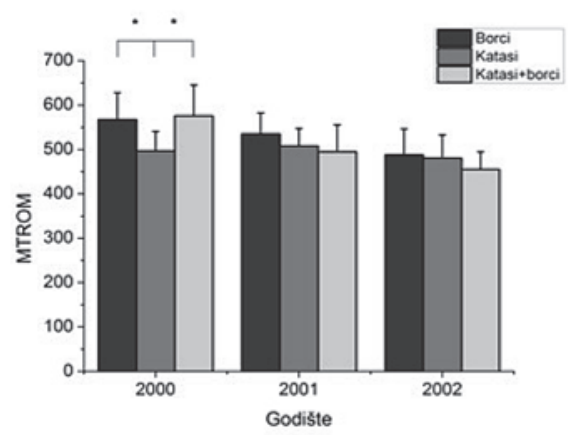

Слика 3 Троскок из места носно такмичарском усмерењу, приказани су на сликама (Слика 1 до Слика 9),

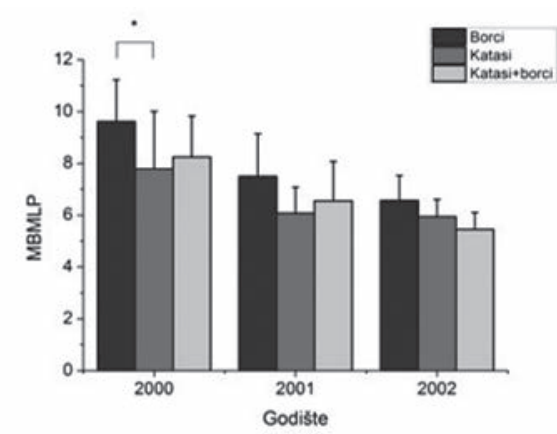

Слика 2 Бацање медицинке из лежећег положаја

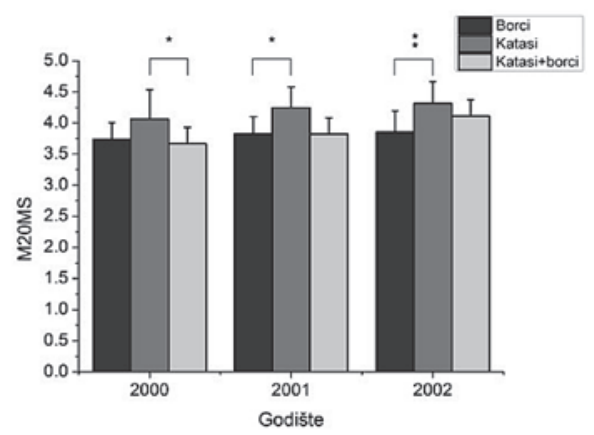

Слика 4 Трчање 20 метара (sec) 


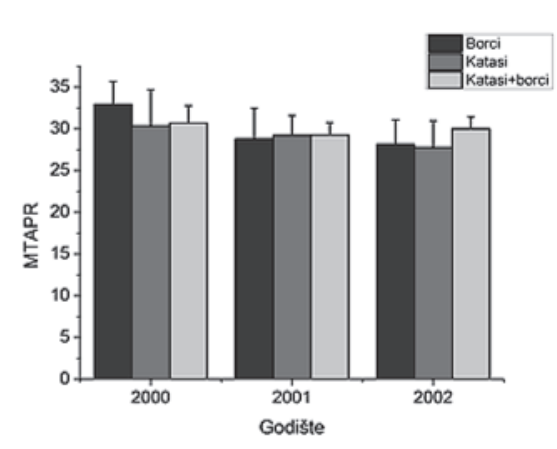

Слика 5 Тапинг руком за 15 секунди

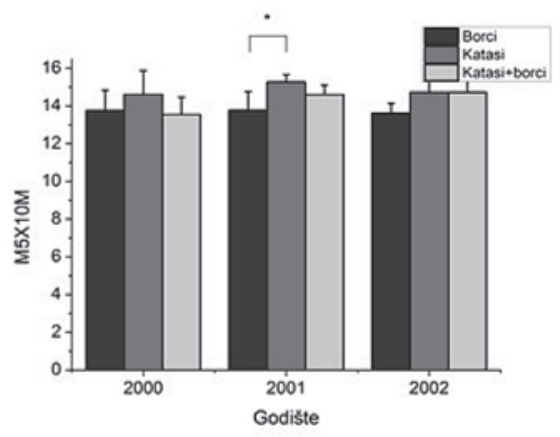

Слика 7 Трчање $5 \times 10 \mathrm{~m}$

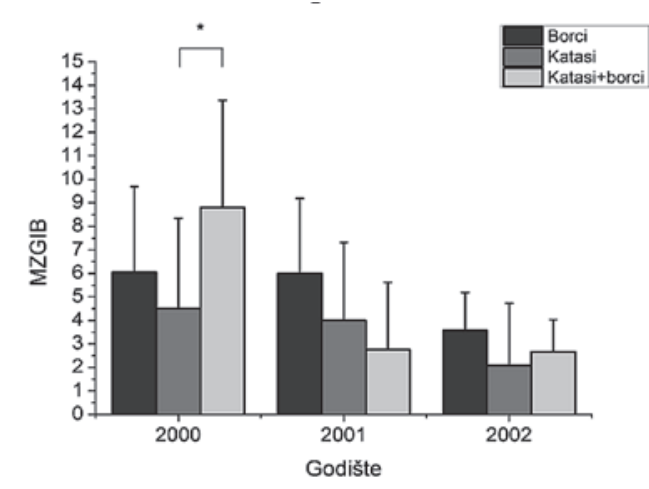

Слика 9 Згибови на вратилу

\section{ДИСКУСИЈА}

На основу досадашњих истраживања (Додер и Додер, 2006; Блажевић, Катић, \& Поповић, 2006; Додер и Бабиак, 2007; Блажевић, Жаја, \& Катић, 2008; Божанић \& Бешлија, 2010; Гужвица, 2011), можемо рећи да су карате вештине у „позитивној“ корелацији са базичним моторичким способностима, а као најзначајније способности, оне које битно утичу на кретање и избор техника, које такмичар најчешће користи у борби, истичу се ек-

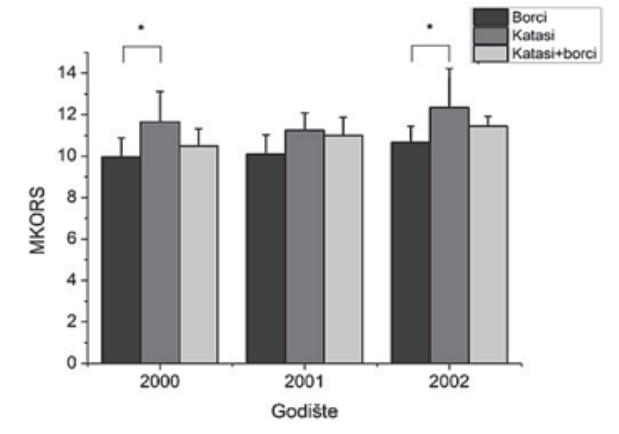

Слика 6 Кораци у страну (sec)

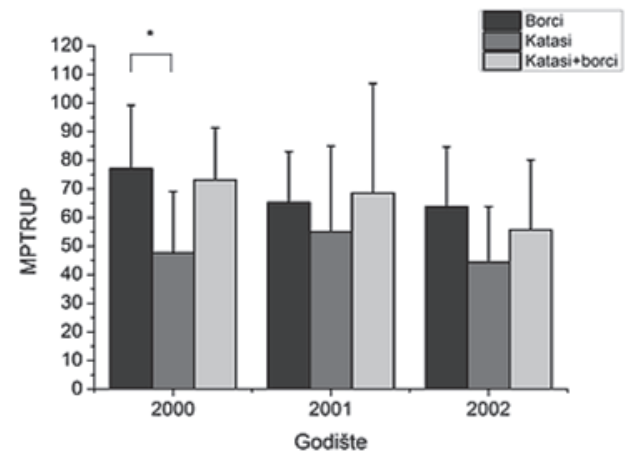

Слика 8 Подизање трупа из лежећег положај

сплозивна снага, брзина, координација и гипкост. Као последица специфичних моторичких захтева који су претходили такмичарској специјализацији за конкретну такмичарску дисциплину, било је за очекивање да ће се појавити извесне разлике између испитиваних група каратиста.

На основу резултата дескриптивне статистике моторичких варијабли читавог узорка, [аритметичка средина (стандардна девијација)] према узрасту, односно такмичарском усмерењу, који су приказани на сликама (Слика 1 до Слика 9), констатујемо да борце описују незнатно веће 
вредности од каташа, односно каташа+бораца. У варијаблама за процену експлозивне снаге (МСДАљ, МБМЛП, МТРОМ), резултати бораца у односу на резултате каташа, значајно су бољи само код најстаријих испитаника. Та разлика се смањује када се анализирају резултати млађих каратиста. Слична је ситуација и код анализе брзине, где су у варијабли М20MC, борци значајно бољи у односу на каташе, што је нарочито испољено код најмлађих испитаника. Код фреквенције покрета нема значајних разлика између група, осим код најстаријих такмичара (2000. годиште), где су борци мереним параметриима „надмоћнији“ од осталих група испитаника. У моторичкој координацији, такође, борци имају боље резултате, с тим што те вредности нису значајније веће, осим у једној варијабли (МКОРС), код најстаријих (2000. годиште) и најмлађих (2002) испитаника. Борци су, такође, значајно бољи у односу на каташе у варијабли М5X10М код најстаријих испитаника.

У простору гипкости није било значајних разлика између група у односу на такмичарско усмерење, мада су резултати бораца бољи, каташи су значајно слабији у односу на остале две групе испитаника. У само једној варијабли (МЗГИБ) код репетитивне снаге, група која се такмичи у обе дисциплине, значајно је боља у односу на друге две групе испитаника, и то код најстаријих (2000. годиште) такмичара.

Када се упореде резултати овог са недавним сличним истраживањима Коропановског и сарадника (Коропановски и сар, 2011, 2012), може се рећи да нема великих разлика међу овим студијама. Као и у овом, тако су и у истраживању Корапановски и сар., (2011), борци су показали боље резултате на тестовима за процену брзине и експлозивне снагу, док се у простору гипкости разликују резултати. У овој способности такмичари у катама, за разлику од овог истраживања, имали су боље резултате, али нешто испод нивоа значајности. То се може приписати чињеници да се у том истраживању испитаници били врхунски каратисти, а каташи у савременом каратеу изводе технику из, релативно, ниских ставова. У тренингу каташа се, из тог разлога, посвећује већа пажња повећању покретљивости, нарочито доњих екстремитета. У нешто новијем истраживању, Корапановски (2012), је испитивао карактеристике врхунских такмичара у катама и борбама, применом тестова опште и специфичне моторике у ра- зличитим режимима мишићног напрезања.

Мултиваријантна анализа коваријансе указала је да је утицај телесне висине на резултате моторичких тестова значајан. Када се резултати моторичких тестова пореде релативно у односу на телесну висину, не уочавају се значајне разлике у простору моторике између испитаника различитог узраста ,али је зато фактор спортско усмерење у овом случају био значајан. Накнадна анализа показала је да је телесна висина имала значајни утицај на варијабле МСДАљ, МБМЛП, МТРОМ, М20MC. Релативно у односу на телесну висину, фактор узраст био је значајан у случају МБМЛП, МЗГИБ, док је фактор „такмичарско усмерење“ био значајан у случају највећег броја варијабли (МБМЛП, М20МЦ, МТРАП, МКОРС, М5Х10М, МПТРУП). Разлике у односу на узраст, односно такмичарско усмерење (укрштени фактори) биле су конзистентне за све моторичке варијабле. Накнадна анализа показала је да је највећи број значајних разлика добијен у најстаријем узрасту (2000. годиште) и то у корист бораца, односно бораца+каташа у односу на каташе.

\section{ЗАКЉУЧАК}

Циљ студије, која је обухватила широк спектар показатеља, био је да се испита предиктивна вредност моторичких способности каратиста у такмичарској селекцији, односно у њиховој такмичарској оријентацији према конкретној дисциплини: за кате или борбе. У функцији дефинисаног циља, истражене су разлике испитаника различите такмичарске оријентације. Евентуални утицај моторичких способности на опредељење испитаника за такмичарску дисциплину, покушали смо да пронађемо тестирањем њихових разлика. Како би проценили општу моторику каратиста, примењена су по три теста за најзначајније моторичке способности које утичу на кретање и избор техника које такмичар најчешће користи у борби. Као последица специфичних моторичких захтева у конкретној такмичарској дисциплини, било је за очекивање да ће се појавити извесне разлике између испитиваних група каратиста, што се и потврдило добијеним резултатима. Тиме је и потврђена постављена хипотеза о предиктивним вредностима моторичких способности у такмичарској селекцији каратиста. Треба напоменути 
да је истраживање спроведено на популацији каратиста који су у периоду интензивног раста и развоја па би овакво или слично исртаживаље требало урадити са популацијом каратиста старијих узраста, како би дошли до поузданијих резултата. Истраживање представља допринос методици и

\section{ЛИТЕРАТУРА}

1. Братић, М. (2006). Борења. Ниш: Факултет спорта и физичког васпитања.

2. Blažević, S., Katić, R., \& Popović, D. (2006). The effect of Motor Abilities on Karate Performance. Coll. Antropol., 30 (2), 327-333.

3. Blažević, S., Žaja, M., \& Katić, R. (2008). Integration and basic specific motor abilities in elite karateka. Zagreb: $5^{\text {th }}$ International Scientific Conference on Kinesiology - Kinesiology research blends and applications, 891-893.

4. Božanić, A., \& Bešlija, T. (2010). Relations Between fundamental motor skills and specific karate tech nique in 5-7 year old beginners. Sport Science 3 (1), 79-83.

5. Додер, Д., и Додер, Р. (2006). Утицај антрополошких карактеристика на успешност из-

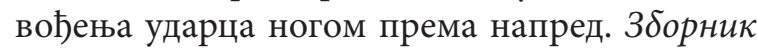
Майице срйске за йрирояне науке, 111, 4554.

6. Doder, D., i Babiak, J. (2007). Povezanost eksplozivne snage sa vrhunskim rezultatima u karateu. MONTENEGRIN SPORT ACADEMY, „Sport Mont"12,13,14 (B), 784-791.

7. Gužvica, M. (2011). Prediktivnost kvaliteta izvođenja nožnih tehnika u karate sportu na osnovu nekih motoričkih sposobnosti i morfoloških karakteristika. 3. Međunarodni naučni kongres "antropološki aspekti sporta, fizičkog vaspitanja $i$ rekreacije", Banja Luka, Zbornik radova, 94-104.

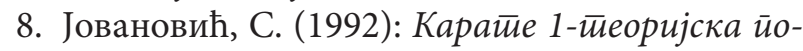
тазиштиа, уибеник. Sports World, Нови Сад. технологији тренинга у карате спорту због веома малог броја истраживања посвећених испитивању разлика између каратиста различите такмичарске оријентације. Резултати могу да послуже као основа и подстицај за будућа истраживања у каратеу.

9. Koropanovski, N., Berjan, B., Bozic, P. B., Pazin, N., Sanader, A., Jovanovic, S., \& Jaric, S. (2011). Anthropometric and Physical Performance Profiles of Elite Karate Kumite and Kata Competitors. Journal of Human Kinetics, 30, 107-114.

10. Корапановски, Н. (2012). Каракиеерисиике неуромишићне функиије врхунских каратиистиа различите сиецијализачије. Необјављена докторска дисертација, Београд: Факултет спорта и физичког васпитања.

11. Курелић, Н., Момировић, К., Стојановић, М., Штурм, Ј., Радојевић, Ђ., и Вискић-Шталец,

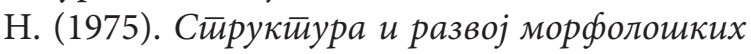
и мотиоричких gимензија омлаgине. Београд: Факултет за физичко васпитање.

12. Савић, М., Нићин, Ђ., Хорват, С., и Копас, J. (1994). Борилачки сйорйови. Нови Сад, Факултет физичке културе.

13. Ћирковић, 3., и Јовановић, С. (2002). Борењьа,

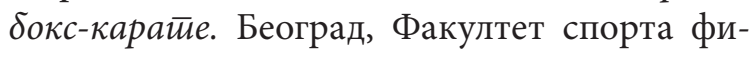
зичког васпитања.

14. Ћирковић, 3., Јовановић, С., и Касум, Г. (2010). Борењь. Београд:, Факултет спорта физичког васпитања.

15. Живановић, Н., Станковић, В., Ранћеловић, Н., и Павловић, П. (2010). Теорија физичке кулимуре. Ниш, Факултет спорта и физичког васпитања. 


\title{
CAPACIDADES MOTRICES COMO PREDICTORES DE LA SELECCIÓN COMPETITIVA EN KARATE
}

\begin{abstract}
Resumen
El objetivo del presente estudio es investigar el valor predictivo de las capacidades motrices de los jóvenes karatekas en su orientación competitiva hacia la disciplina concreto: para katas o para luchas. En relación con el objeto y objetivo fijados, se estableció la hipótesis que las capacidades motrices son un predictor importante de la selección competitiva en karate. La muestra de los examinados eran los karatekas varones, de edades cronológicas de 12 a 14 años quienes están en un proceso de entrenamiento regular y compiten en marco del sistema actual de competencias. La investigación abarcó 79 karatekas en total, de los que los 37 competidores en luchas, 23 competidores en katas y los 19 examinados que computen en las dos disciplinas. Para evaluar la motricidad general de los examinados se han aplicado 15 pruebas como sigue: tres pruebas para la fuerza repetitiva, fuerza explosiva, rapidez, coordinación y flexibilidad respectivamente. Se han establecido los parámetros estadísticos descriptivos, se ha hecho el análisis extendida de covarianza (MANCOVA) y análisis de covarianza (ANCOVA). La importancia estadística se ha analizado en el nivel $(\mathrm{p}<0.05)$. Los resultados obtenidos confirman la hipótesis establecida de valores predictivos de las capacidades motrices escogidas en la selección competitiva de karatekas.
\end{abstract}

Palabras claves: KARATE / CAPACIDADES MOTRICES / NIÑOS

Примљен: 16.11.2017

Прихваћен: 07.03. 2018 